\title{
Mütareke Döneminde Asri Kadın Cemiyeti’nin Faaliyetleri
}

\section{Activities of Asri Kadin Cemiyeti During the Armistice Period (1918-1923)}

Nuray ÖZDEMIR* ${ }^{*}$ (D)

*Prof. Dr., Bolu Abant İzzet Baysal Üniversitesi, Bolu, Türkiye

ORCID: N.Ö. 0000-0003-0001-6427

Sorumlu yazar/Corresponding author: Nuray Özdemir,

Bolu Abant İzzet Baysal Üniversitesi, Bolu, Türkiye

E-posta/E-mail: ozdemir_n@ibu.edu.tr

Başvuru/Submitted: 24.10 .2020 Revizyon Talebi/Revision Requested: 29.12.2020

Son Revizyon/Last Revision Received: 06.01.2021

Kabul/Accepted: 13.01 .2021

Atıf/Citation: Ozdemir, Nuray. "Mütareke Döneminde Asri Kadın Cemiyeti'nin Faaliyetleri" Yakın Dönem Türkiye Araștırmaları-Recent Period Turkish Studies 39 (2021): 107-133.

https://doi.org/10.26650/YTA2021-815801

\section{öz}

Asri Kadın Cemiyeti, Millî Mücadele döneminin en etkin kadın cemiyetlerinden biridir. Cemiyet, 1918 yılı sonlarında İstanbul'da İnas Darülfünunu mezunları ve öğrencileri tarafından kurulmuştur. Amacı kadınları bedenen ve fikren eğitmek ve toplumsal konumlarını yükseltmek olmuştur. Naciye Faham, Şukufe Nihal, Aliye Esad, Sabahat, Saime Hanımlar cemiyetin öne çıkan isimleridir. Mondros Mütarekesi sonrasında başlayan işgalleri protesto amaçlı ilk toplantı Asri Kadın Cemiyeti'nin öncülüğünde 19 Mart 1919'da Fatih türbesinde yapılmıştır. Cemiyet, İzmir'in işgali üzerine protesto amaçlı düzenlenen Üsküdar, Kadıköy ve Sultanahmet mitinglerine de destek vermiştir. Bu mitinglerde cemiyet üyeleri etkili konuşmalar yapmışlardır. Cemiyet, İstanbul'un resmen işgali sonrasında pek etkinlik gösterememiştir.

Bu çalışmada, mütareke döneminde İstanbul'da kurulan Asri Kadın Cemiyeti'nin faaliyetleri incelenmiştir. İşgaller karşısında cemiyetler etrafinda örgütlenen kadınların Millî Mücadelenin kazanılmasındaki rolü değerlendirilmiştir.

Anahtar Kelimeler: Asri Kadın Cemiyeti, Mütareke Dönemi, İstanbul, Kadın, Protesto

\section{ABSTRACT}

Asri Kadın Cemiyeti (Association of Modern Women) was one of the most effective women's associations during the National Struggle period. Founded in Istanbul at the end of 1918 by graduates and students of İnas Darülfünunu (Women's University), its aims were to educate women physically and mentally and to raise their social status. Naciye Faham, Şukufe Nihal, Aliye Esad, Sabahat, and Saime Hanım were outstanding figures in the Association. The first meeting to protest the occupations was organized immediately after the Armistice of Mudros and was held in Fatih Tomb on March 19, 1919 under the leadership of Asri Kadın Cemiyeti. The Association also supported protests held in Üsküdar, 
Kadıköy, and Sultanahmet against the occupation of İzmir. During these protests, members of the Association delivered impressive speeches. The Association could take little action after the official occupation of Istanbul.

This study engages in research into the activities of Asri Kadın Cemiyeti during the armistice period. Its objective is to evaluate the role of women, organized through associations in the face of occupation, in winning the National Struggle.

Keywords: Association of Modern Women, Armistice Period, Istanbul, Women, Protest

\section{Extended Abstract}

Women played a role in every phase of the National Struggle and provided significant support both on and behind the front lines during the country's occupation. The most comprehensive and well-organized of women's activities during the National Struggle involved women's associations, which actively sought to raise public awareness and to communicate the National Forces' spirit to the populous. The most effective associations of this period were Asri Kadın Cemiyeti (Association of Modern Women) in İstanbul, Hilal-i Ahmer Center for Women, the Women's Branch of Müdafaa-i Hukuk Cemiyeti (Association for Defense of National Rights) in Anatolia, and the Anatolian Women's Association for the Defense of the Homeland.

One such women's Association during the National Struggle, Asri Kadin Cemiyeti, was founded in İstanbul in late 1918 by students and graduates of İnas Darülfünипи. The Association was also supported by notable authors and academics of the period like Halide Edip (Adıvar), Nakiye (Elgün), Nezihe Muhiddin Hanım. The Head of the Association was Darülfünun graduate Naciye Faham Hanım and the Secretary General was Aliye Esad Hanım. Among its members were İstanbul intellectuals like Şukufe Nihal (Başer), Sabahat (Filmer), and Selma Köprülü. Its aims were to educate women physically and mentally and to raise their social status. To achieve this, the Association planned to establish a library, museum, laboratory, and workshops.

The headquarters of Asri Kadin Cemiyeti was Bilgi Yurdu and most meetings were held in the hall of Malul Gaziler Cemiyeti (Association of the War Wounded), also used as the Central Army Office of Cinema. The Association's first task was to organize women in the face of the occupations that followed the Armistice of Mudros. The Association took leadership in protesting, holding the first open-air meeting for women in Fatih Tomb on March 19, 1919. Association Head Naciye Feham Hanım delivered a sentimental speech on the perilous situation of the nation. The slogans shouted in this protest, emphasizing the Turkishness of İstanbul and that İstanbul belongs to the Turks, mobilized national sentiment among women. 
Asri Kadın Cemiyeti also sought to engage in cooperative action with other women's associations in İstanbul against the occupations. It organized a meeting on March 28, 1919, attended by ten women's associations active in İstanbul. Asri Kadın Cemiyeti also strengthened the spirit of resistance among İstanbul women by participating in the National Congress Association that helped to organize national resistance. The occupation of İzmir by the Greeks on May 15, 1919 deeply affected members of Asri Kadın Cemiyeti. The Association supported protests organized in various neighborhoods of İstanbul under the initiative of Turkish Hearts. Members of the Association showed great interest in the demonstrations both as contributors and as members of the audience in Üsküdar on May 20, 1919, in Kadıköy on May 2, 1919, and in Sultanahmet on May 23, 1919 and January 13, 1920. In open-air meetings held in İstanbul, for the first time women delivered speeches to gatherings of men and women. Naciye Faham Hanım, Sabahat Hanım, and Şukufe Nihal Hanım of Asri Kadın Cemiyeti gave exciting speeches stressing Turkishness. They moved the crowd with speeches emphasizing Muslimism, patriotism, femininity, freedom, motherhood, and martyrdom. They cried out that they were ready to struggle together with men for the integrity of the country and the sovereignty of the nation.

The Association undertook cultural activities in line with its founding purpose and held training courses for women, including literacy, French, German, and English courses. Asri Kadin Cemiyeti became the representative of modern women in İstanbul and an authority on issues surrounding women's rights. Most of the members, who were among the first postgraduate women in Turkey, taught at schools and strived to advance the education and rights of women. The Association could take little action after the official occupation of İstanbul on March 16, 1920, but it followed the National Struggle in Anatolia with interest. Indeed, following his victory at the Battle of Sakarya, Commander in Chief Mustafa Kemal Pasha was sent a letter of congratulations signed by Naciye Faham, Head of the Association. While the activities of Asri Kadin Cemiyeti ended in the Republican Period, its members remained active in organizations like the Turkish Women's Union.

This study will analyze the activities of Asri Kadın Cemiyeti, which was founded by the students and graduates of Inas Darülfünunu in İstanbul, during the armistice. Particular emphasis will be placed on the periodic importance of the protests led by the Association. The role and importance of women, organized through associations in the face of occupation, in achieving victory in the National Struggle will then be evaluated. 


\section{Giriş}

Osmanlı Devleti'nde her alanda olduğu gibi kadının statüsünde de değişim Tanzimat dönemiyle birlikte başlamıştır. Kızların eğitimine önem verilerek kız rüştiyeleri açılmıştır. Kadınlar, öğretmenlik yaparak çalışma hayatına da girmişlerdir. Özellikle II. Meşrutiyet'in ilanının yarattığı özgürlük ortamında başlayan kadın hareketi, kurulan cemiyetlerle kısa sürede gelişme göstermiştir. Batı'da olduğu gibi Osmanlı Devleti'nde de ilk kadın örgütleri yardım dernekleri olarak kurulmuştur. İstanbul'un tanınmış ailelerine mensup iyi eğitim görmüş kadınlar, hem yardım toplamak hem de başta eğitim gibi kadın haklarını savunmak amacıyla örgütlenmişlerdir. ${ }^{1}$ Bu cemiyetler kadının sosyalleşmesinde ve çalışma hayatına girişinde önemli bir işlev görmüştür. Kadın sorunu bu cemiyetler aracılığıyla kamuoyunun dikkatini çekmiş kadın-erkek eşitliği cemiyetlerin toplumsal yaşama aktif katılımıyla gerçekleşmiştir. ${ }^{2}$

Balkan Savaşları ve I. Dünya Savaşı kadınların sosyal ve iktisadi hayatta daha etkin bir şekilde yer almasına yol açmış, Osmanlı kadını öğretmenlikten memurluğa değişik iş alanlarında kendini göstermeye başlamıştır. Birçok iş alanında erkek işgücü açığı nedeniyle kadınlar çok hızlı bir şekilde çalışma hayatı içinde yer almışlardır. ${ }^{3}$ Savaş yıllarında kadın örgütlerinin sayısında da büyük bir artış yaşanmıştır. Teali Nisvan Cemiyeti, Asker Ailelerine Yardımcı Hanımlar Cemiyeti, Himaye-i Etfal Cemiyeti, Topkapı Fukaraperver Cemiyeti, Osmanlı Türk Hanımları Esirgeme Derneği, Biçki Yurdu, Osmanlı Kadınları Çalıştırma Cemiyet-i İslamiyyesi, Osmanlı Kadınlar Cemiyeti, Hilal-i Ahmer Cemiyeti Hanımlar Merkezi, Müdafaa-1 Milliye Hanımlar Heyeti, Müdafaa-1 Hukuk-u Nisvan Cemiyeti, İstihlak-1 Milli Kadınlar Cemiyeti en etkin kadın örgütleri olmuşlardır. ${ }^{4}$ Yaralı askerlere sağlık hizmeti veya ordunun ihtiyaçlarının karşılamaya yönelik giyim ve diğer maddi yardımlar kadın cemiyetlerinin faaliyetleri sonucunda sağlanabilmiştir.

I. Dünya Savaşı sırasında kadınların çalışma hayatına girişini ve cemiyetler etrafında örgütlenmesini Emine Semiye, Aliye Esad gibi dönemin öne çıkan yazarları "kadın inkılabı" olarak değerlendirmiştir. Daha sonra Asri Kadın Cemiyeti’nin kurucuları arasında da yer alacak Aliye Esad Hanım Ati Gazetesi'ne Darülfünunlu genç kadınlar adına gönderdiği bir bildiride, savaş sonrasında kadınlar lehine yaşanan gelişmelere değinerek

\footnotetext{
Leyla Kaplan, Cemiyetlerde ve Siyasi Teşkilatlarda Türk Kadını (1908-1960), Ankara, ATAM Yayınları, 1998, s.38.

Zafer Toprak, Türkiye'de Kadın Özgürlüğ̈̈ ve Feminizm (1908-1935), İstanbul, Tarih Vakfı Yurt Yayınları, 2014, s.18.

Zafer Toprak, Türkiye'de Yeni Hayat İnklap ve Travma (1908-1928), İstanbul, Doğan Kitap, 2017, s.52.

Serpil Çakır, Osmanlı Kadın Hareketi, İstanbul, Metis Yayınları, 2011, s.87-103.; Bernard Caporal, Kemalizmde ve Kemalizm Sonrasında Türk Kadını (1919-1970), Ankara, Türkiye İş Bankası Kültür Yayınları, 1982, s.149-150.
} 
Darülfünun öğrencilerinin kadınların yükselmesi için çalışmaya azmettiğini şöyle ifade etmiştir: ${ }^{5}$

"Memleketimizde kadınlık "asırlardan beri menfi bir vaziyette bırakılmış, derin bir boşluk içinde kalmıştır. Türk kadınlı̆̆ını bugünün layık gördüğü mevki-i ihtirama (yüksek mevkiye) çıkarmak için ilmi, edebi, ahlaki sahalarda ibraz ettiği faaliyetle genç neslin genç kadınlığ yüksek bir seviye-i medeniyyeye i'sada (yükseltmeye) hadim ve müfid bir inkılap fikri yapmak maksadıyla bütün Darülfünun talebatı (ögrencileri) el ele vermişler, bu uğurda ideal mesai ve fedakariye azmetmişlerdir. ${ }^{6}$

I. Dünya Savaşı ile kadının statüsünde büyük bir değişim yaşanırken bundan sonra kadınlar ülke sorunları ile daha çok ilgilenmeye başlamışlardır. Mondros Mütarekesi ertesinde başlayan işgallere en sert tepkiler savaş yıllarında milliyetçi kimliği şekillenmeye başlayan Türk kadınından gelmiştir. Mütareke döneminde halkı bilinçlendirip milli direniş ve Kuva-yı Milliye ruhunu geniş kitlelere yaymada kadın cemiyetleri önemli rol oynamıştır. ${ }^{7}$

Bu çalışmada, 1918 yılı sonlarında kültürel açıdan kadınları bilgilendirmek, geliştirmek amacıyla İstanbul'da İnas Darülfünunu mezunları ve öğrencileri tarafından İstanbul'da kurulan Asri Kadın Cemiyeti'nin faaliyetleri incelenmiştir. Cemiyetin, Mondros Mütarekesi sonrasında başlayan işgaller karşısında kadınları örgütlemeye yönelik çalışmaları ve protesto mitinglerindeki öncülüğü üzerinde durulmuştur. Ayrıca mütareke dönemi İstanbul'unda kadınlara yönelik faaliyetleri incelenmiştir. İşgaller karŞısında cemiyetler etrafında örgütlenen kadınların Millî Mücadelenin kazanılmasındaki rolü değerlendirilmiştir.

\section{Asri Kadın Cemiyeti’nin Kuruluşu}

I. Dünya Savaşı sonrasında "kadın meselesi” özellikle dönemin gazete ve dergilerinde en çok üzerinde durulan konulardan biri olmuştur. Bu süreçte İnas Darülfünunu ${ }^{8}$

5 Yaprak Zihnioğlu, Kadınsız İnkılap, İstanbul, Metis Yayınları, 2013, s.83.

6 “Türk Kadınlığı Hakkında", Ati, 26 Nisan 1918, s.4.

7 Leyla Kaplan, Cemiyetlerde ve..., s.72.

8 İnas Darülfünunu, 1914 yılında İstanbul'da Zeynep Hanım Konağı'nda açılmış edebiyat ve fünun (riyaziyat ve tabiyyat) şubelerinden oluşturulmuştur. Osmanlı Devleti'nde ilk defa kadınların yüksek öğretim gördüğü İnas Darülfünunu'nda 22 öğrenci ile eğitime başlanmış ve ilk mezunlar 1917 yılında verilmiştir. Okuldan mezun olan ilk öğrenciler İstanbul'daki İnas idadi ve sultanileri ile ülkenin çeşitli yerlerinde bulunan Darü'l-muallimat'lara atanmışlardır. Öğrencilerin karma eğitime geçilmesi yönündeki talepleri üzerine İnas Darülfünunu 1919 yılında kapatılarak Darülfünun'a bağlanmıştır. İnas Darülfünun'un eğitim verdiği beş yılda okuldan 53 öğrenci diploma almıştır. İnas Darülfünunu öğrencileri ve mezunları aydın Osmanlı kadınının yüzü olmuşlardır. Mütareke döneminde Asri Kadın Cemiyeti, Müdafaa-1 Hukuk-1 Nisvan Cemiyeti gibi kadın örgütleri ile Anadolu'daki milli direniş hareketine yardımcı olan Karakol Cemiyeti gibi gizli örgütlenmelerde de görev almışlardır. Bkz: Bahar Baskın, "II. Meşrutiyet’te Kadın Eğitimine Yönelik Bir Girişim: İnas Darülfünunu”, İ. U. Siyasal Bilgiler Fakültesi Dergisi, No:38, Mart 2008, s.91-100. 
mezunları ve öğrencileri de tartışmaların merkezinde yer almışlardır. Türk kadınının konumunu yükselmek için Darülfünunlu kadınların el ele verip çalışmak için bir girişimde bulundukları Ati Gazetesi'nde Kâtibe Aliye Esad Hanım'ın imzasıyla “Heyet-i müteşebbise namına" yayınladığı yazı ile kamuoyuna duyurulmuştur. Aliye Esad Hanım bu girişimin sekreteri olarak Darülfünunlu kadınların örgütlendiğini ilan etmiştir. ${ }^{9} \mathrm{Bu}$ girişim dönemin basınında da övgüyle yer bulmuştur. Yayın hayatına yeni başlayan Türk Kadını Dergisi “İnas Darülfünunlu Hanımlarımızın Bir Teşebbüsü” başlığıyla bir yıl gibi uzun bir zamandır kuruluş aşamasında olan cemiyete ilk sayılarında uzun uzun yer vermiştir. Cemiyetin kuruluşundan duyulan memnuniyete dair derginin ilk sayısında yapılan bir haberde şunlara yer verilmiştir:

"Şimdi memnuniyetle görüyoruz ki, yeni yetişen ilk genç kız hayatı derhal etrafina keskin nazarlar firlatarak pek çok himmetlere muhtaç bulunan kadınlığın eline sarılmış, onu sahil-i selamete çıkarmak istiyor.

Buna birinci delil de son zamanlarda haber aldığımı İnas Darülfünunu mezunlarının teşkil etmekte olduğu cemiyettir. En son merhale tedris kat etmiş münevver hanımların elleriyle kurulacak bu cemiyetin istikbalinden pek eminiz." 10

Darülfünunlu kadınların cemiyetin kuruluşu sürecinde büyük bir azim ve ihtiyat içinde oldukları aceleci davranılmadığına da dikkat çekilmiştir. Hatta cemiyetin kamuoyunun fikrini alarak hareket ettiği isim konusunda dahi görüş aldığı eklenmiştir. Bu çerçevede Türk Kadını Dergisi de henüz ismi açıklanmayan cemiyete isim konusunda öneriler getirmiştir. Yakın gelecekte kadın-erkek ayrımı kalkacağından cemiyetin isminde “İnas Darülfünunu" yerine "Darülfünun" kelimesine yer verilmesinin uygun olacağ1 belirtilmiştir. Kadınlık İntibahı Cemiyeti, Genç Kadınlar Cemiyeti gibi isim önerilerinde de bulunmuştur. Ancak cemiyetin kuruluş sürecinde çevreye isim konusunda fikir sormasının isim bulamamaktan çok cemiyetin nasıl karşılandığını anlamak için yapıldı$\breve{g} 1$ da ifade edilmiştir. ${ }^{11}$

Nihayet 1918 yılı sonlarında Naciye Faham, Aliye Esad, Sabahat ve Mediha Hanımların öncülüğünde Asri Kadın Cemiyeti'nin ${ }^{12}$ resmen kuruluşu ilan edilmiştir. Altı sayfa ve 22 maddeden oluşan Asri Kadın Cemiyeti Nizamnamesi’nin ilk üç maddesinde cemiyetin kuruluşu ve amacı şöyle belirtilmiştir:

9 “Türk Kadınlığı Hakkında”, Ati, 26 Nisan 1918, s.4.

10 “Darülfünunlu Hanımlarımızın Bir Teşebbüsü”, Türk Kadını, S.1, 23 Mayıs 1918, s.15.

11 “Darülfünunlu Hanımlarımızın Bir Teşebbüsü”, s.15.

12 Dönemin basınında cemiyetin adı "Asri Kadınlar Cemiyeti” olarak da geçmektedir. 
“Madde 1-1334/1918 senesinde merkezi İstanbul'da olmak üzere "Asri Kadın Cemiyeti” namıyla bir cemiyet teşekkül etmiştir.

Madde 2-Cemiyetin maksad,, kadınların bedenen, fikren terbiyesine çalı̧̧arak, içtimaen mevkiini yükseltmektir.

Madde 3-Cemiyet bu gayeye vusul için telkinat ve neşriyatta bulunarak ilmi, sinai encümenler teşkil ve kütüphane, müzehane, laboratuvar, atölye tesis edeceği gibi müessesat-ı ilmiye-i mevcudeden bazılartyla da temin-i münasebet edecektir."

Nizamnameye göre cemiyetin üç çeşit üyesi vardır. Yüksekokullarda öğrenim gören öğrenci veya mezunlardan oluşan asıl üyeler, hanedan mensupları, nazırların eşleri ve cemiyete yardımda bulunan seçkin üyeler ile cemiyetin çalışmalarına yardım eden faaliyetlerine katılan destekçi üyelerdir. Bunlardan cemiyete üye olurken bir defaya mahsus olmak üzere kayıt ücreti olarak 50 kuruş ile yıllık aidat da alınacaktır. Cemiyet genel kurulu olağanüstü bir toplantı ile İstanbul'da bulunan asıl üyelerin üçte birinin katılımıyla nizamnameyi tadil ve sslah edebilecektir. Genel kurul asıl üyelerin katılımıyla düzenli olarak yılda bir kere mayıs ayında içtima ederken lüzum üzerine idare heyetinin çağrısı ile olağanüstü de toplantı yapabilecektir. Cemiyeti asıl üyeler arasından iki seneliğine seçilen ve on kişiden oluşan bir idare heyeti yönetecektir. İdare heyeti kendi içinde bir reise, kâtib-i umumi, kâtib, muhasebeci ve veznedar seçecektir. Cemiyetin gelirleri ise üyelerin yıllık aidatları, bağışlar ile cemiyet tarafından düzenlenecek sergi, konser, müze gelirleri ile cemiyete ait gayrimenkullerden alınacak vergilerdir. Ayrıca cemiyetin ilmi konularda danışıp çalışacağı bir ilmiye heyeti de vardır. Bu heyet konferanslar verip, makaleler yazmakla görevlidir. ${ }^{13}$

13 Türkiye Cumhuriyeti Cumhurbaşkanlı̆̆ A Aş̧ivi (CA), 01019819-3.; Asri Kadın Cemiyeti Nizamnamesi, İstanbul, Minber Matbaası, 1919. 


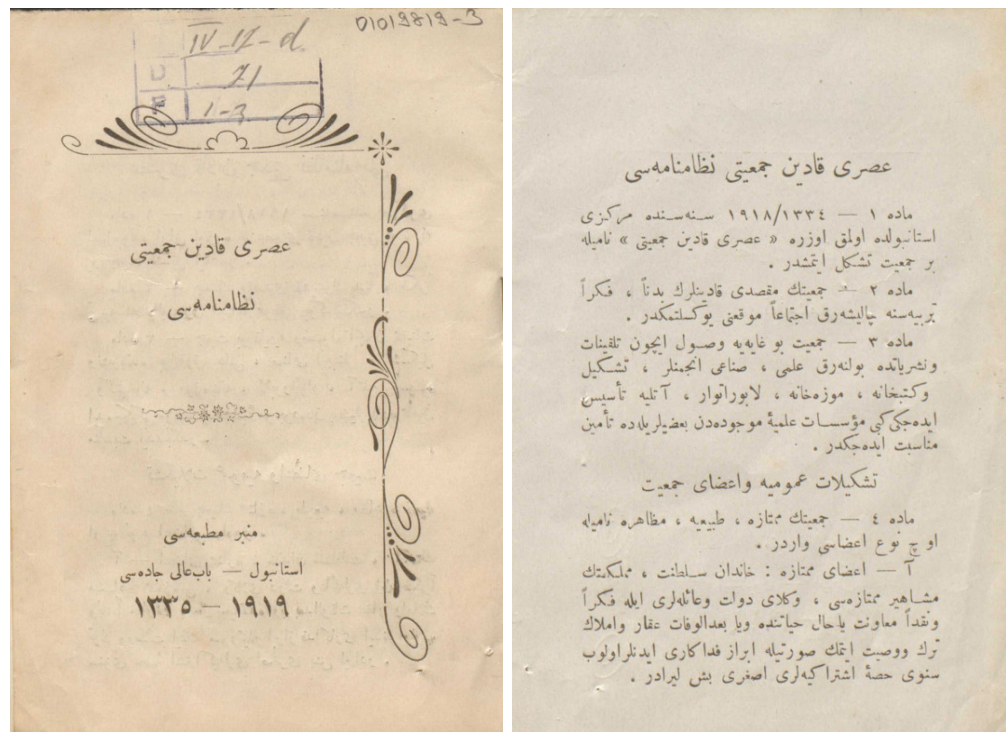

(Asri Kadın Cemiyeti Nizamnamesi, (CA), 01019819-3.)

Asri Kadın Cemiyeti'nin kuruluşu, Halide Edip (Adıvar), Nakiye (Elgün), Nezihe Muhiddin Hanım gibi dönemin öne çıkan yazar ve eğitimcilerince de desteklenmiştir. Cemiyete, İnas Sanayi-i Nefise Mektebi ve Arnavutköy Amerikan Kız Koleji'nde okuyan kız öğrenciler de üye olmuşlardır. Cemiyetin başkanlığını Darülfünun tabiiyyat şubesi mezunu Naciye Faham Hanım, genel sekreterliğini ise edebiyat şubesi mezunu Aliye Esad Hanım yapmıştır. Üyeleri arasında da Şukufe Nihal, Sabahat Hüsamettin, Melahat Hüsamettin, Saime, Saliha Ruşen, Suat, Mihriban, Behice, Naime, Seniha, Zehra, Mediha Süleyman Hanım ${ }^{14}$ gibi İstanbul'un eğitimli kadınları yer almıştır. ${ }^{15}$

Asri Kadın Cemiyeti'nin idare merkezi Divan-1 muhasebat (Sayıştay) civarında Bilgi Yurdu binası olarak ilan edilmiştir. ${ }^{16}$ Ancak cemiyet toplantılarını Ordu Film Merkezi'nce de kullanılan Malul Gaziler Cemiyeti’nin salonunda yapmıştır. Cemiyetin hanımlara yönelik düzenlediği çeşitli kurslar için Bilgi Yurdu'nun dershaneleri kullanılmiştır. ${ }^{17}$

14 Mediha Süleyman Gezgin, İnas Sanayi Nefise Mektebi’nde müzik eğitimi görmüş, müzik ve resim öğretmenliğinin yanında Müslüman Kadınlar Birliği ve Türk Kadınlar Birliği gibi kadın örgütlerinde de görev almıştır. Bkz. Hacer Banu Paşalığlu, Inas Sanayi-i Nefise Mektebi ve Mezunları, Marmara Üniversitesi Türkiyat Araştırmaları Enstitüsü Yayımlanmamış Yüksek Lisans Tezi, İstanbul 1996, s.71.

15 Sabahat Filmer, Atatürk Yolunda Büyük Adımlar, İstanbul, Gül Matbaas1, 1983, s.34.

16 Türkiye Cumhuriyeti Cumhurbaşkanlı̆̆ Devlet Arşivleri Başkanlı̆̆ Osmanlı Arşivi (BOA), DH.EUM.5.Şb, 79-30, 12, H-30-12-1337.

17 Sabahat Filmer, Atatürk Yolunda..., s.34-35. 
Asri Kadın Cemiyeti'nin kuruluşu 1918 yılının son günlerinde olmuşsa da cemiyetin kuruluşuna dair haberler dönemin basınında 1919 yılı Şubat ve Mart aylarında yer bulmuştur. Inci Dergisi, 1 Şubat 1919 tarihli sayısında Kadınlık Şuunu başlıklı köşesinde Asri Kadın Cemiyeti'nin kurulduğuna dair bir habere yer vermiştir. Kadınların "asri hayata hazırlanmak mecburiyetinde olduğu bir dönemde böyle bir cemiyetin kuruluşunun memnuniyetle karşılandığı" belirtilerek cemiyete başarı temennisinde bulunulmuştur. ${ }^{18}$ Müşahede Dergisi'nin 22 Şubat 1919 tarihli sayısında ise cemiyetin kuruluşu şöyle duyurulmuştur:

“Kendilerini bu milletin hakiki mürebbileri gören ve bütün Türk kadınlığını kurtarmayı asil bir borç telakki eden Darülfünunumuzun genç kızları, asri ihtiyaçlarını tatmin etmek ve kadın erkek arasında bir fikr-i tesanüd bir anlaşma muhiti ihsar edebilmek için "Asri Kadın Cemiyeti" isminde bir cemiyet teşkil etmişlerdir." 19

Asri Kadın Cemiyeti'nin kuruluşuyla ilgili en uzun haber yayın hayatına yeni başlayan Genç Kadın Dergisi'nde yer almıştır. Dergi, 13 Mart 1919 tarihli sekizinci sayısında cemiyetin kuruluşunu kamuoyuna ilan ederken İstanbul'un aydın kadınlarının bu girişiminden duyulan memnuniyet şu şekilde belirtilmiştir: ${ }^{20}$

“...Asri Kadın Cemiyeti hayata son olarak bütün iddialara rağmen kadınlı̆̆ın artık yumurtayı kırıp dışarıya çıktığını ilan ediyor.

Işste yarınki anaları, erkeklerin yarınki iş yoldaşları kadınları yarınki cemiyete imanlı ve mefkûreli birer uzvu olarak hazırlamak, onları asri ihtiyaçlarla silahlandırmak gayesiyle teşkil eden "Asri Kadın Cemiyeti”, hayatımız için yeni bir tekâmül safhası olmak üzere selamlar. Ve emellerimizi canlandıran müesseseleri önünde hürmetle eğiliriz.

Asri Kadın Cemiyetinin kati ihtiyaçlar neticesinde doğan ve hayatımızda azim bir boşluğu dolduran bir müessese olduğundan şüphe edilemez...

Genç Kadın, neşriyatıyla Asri Kadın Cemiyetinin mefkûresine hizmet edebilirse kendini bahtiyar addedecektir."

Asri Kadın Cemiyeti'nin kuruluş haberine Genç Kadın Dergisi’nde geniş yer verilmesi ve derginin cemiyetin fikirlerini yaymaya hizmet edeceğine dair açıklaması cemiyet yönetimini oldukça memnun etmiştir. Kadınlığın yükselişi için kurulan cemiyete, aynı gaye ile yayın yapan Genç Kadın Dergisi’nin verdiği destek için Asri Kadın Cemiyeti başkanı adına kâtip-i umumi Aliye Esad Hanım "Genç Kadın Mecmuası Heyet-i Tahririye Müdüriyetine" başlığıyla 20 Mart 1919 tarihli uzun bir teşekkür yazısı göndermiştir. Yazısında cemiyetin kuruluş amacını şöyle ifade etmiştir:

18 “Asri Kadın Cemiyeti”, Inci, S.1, 1 Şubat 1919, s.2.

19 “Asri Kadın Cemiyeti”, Müşahede, , S.5, 22 Şubat 1919, s.228-229.

20 “Asri Kadın Cemiyeti”, Genç Kadın, S.6, 13 Mart 1919, s.84. 
"Memleketin buhranll, bu alil günlerinde onu seven ve düşünen kızları lakayt kalamazlardl. Bilhassa kadın, cemiyet hayatınin ufuklarında dolaşıp merkezine giremedikçe milletin terakki ve tekâmülü noksan kalacă̆ için medeniyetini seven ve isteyen bir zümre susamaz ve uyuklayamazdı. Genç Kadın bu asil hisle mesai yollarına çıktı. Cemiyetimiz de küçük fakat azimkâr adimlarla bu yolu yolcusudur."

Çünkü artık herkes öğrendi ve hepimiz anladık ki milletin bir nısfi olan kadınlık uyudukça bize rahat halas yoktur. Asırların manasız taassubu bizi pek haksızca susturmuş senelerin lüzumsuz mantıksız muhafazakârlı̆̆ı kadınlı̆̆ı pek ă̆ır yaralamıştı. Millet yükselemedi... "21

Aliye Esad Hanım'ın aynı amaçla yola çıkan Genç Kadın Dergisi’nden Asri Kadın Cemiyeti'ne desteğini sürdürmesi isteğiyle son bulan yazısının hemen altında Genç Kadın Dergisi de bir teşekkür mesajı yayınlamıştır.

\section{Asri Kadın Cemiyeti ve Mustafa Kemal Paşa}

Asri Kadın Cemiyeti'nin kurulduğu günlerde Mustafa Kemal Paşa İstanbul'dadır. “Anafartalar kahramanı" olarak büyük bir şöhret kazanan Mustafa Kemal Paşa, cemiyet üyelerince "şeref üyesi” yapılmak istenmiştir. Cemiyetin kurucu üyelerinden olan Sabahat Filmer anılarında bu konuda şunları anlatmaktadır: “... Bunu candan istiyorduk. Saliha Ruşen'le Sema Köprülü ve bizim aile dostumuz hem de doktorumuz olan Dr. Rasim Ferit Bey'e bu fikrimizi bildirdiğimiz zaman bizlere cesaret verdi. Kabul edeceğinden emin olduğunu, teklifi yapmamızı söyledi. Paşa'ya bizleri anlatacă̆ını, hatta desteklemeyi vadetti." 22 Dr. Rasim Ferit (Talay) Bey Mustafa Kemal Paşa'nın mütareke dönemi Şişli günlerinde en güvendiği ve destekçisi olan isimlerden biridir. ${ }^{23}$ Mustafa Kemal Paşa'yı Asri Kadın Cemiyeti'nin faaliyetleri hakkında bilgilendirerek Darülfünunlu kadınların üyelik tekliflerini iletmiştir. Hatta iki hafta sonra birlikte cemiyete bir ziyarette bulunmuşlardır. Aslında Mustafa Kemal Paşa, Rasim Ferit Bey ile Ordu Film Merkezi’nde bir manevra filmini görmeye gitmiştir. Asri Kadın Cemiyeti’nin burada toplantı halinde olduğunu öğrenince cemiyet üyeleri ile görüşmek ve onları tanımak istemiştir. Mustafa Kemal Paşa'nın bu ani ziyaretini Sabahat Filmer anılarında şöyle aktarmaktadir: ${ }^{24}$

21 “Genç Kadın Mecmuası Heyet-i Tahririye Müdüriyetine”, Genç Kadın, S.8, 10 Nisan 1919, s.116.

22 Sabahat Filmer, Atatürk Yolunda..., s.34.

23 Fethi Tevetoğlu, “Atatürk’ün Güvendiği Bir Kişi: Dr. Rasim Ferit Talay”, Atatürk Araştırma Merkezi Dergisi, C.VII, S.21, Temmuz 1991, s.624-625.

24 Sabahat Filmer, Atatürk Yolunda..., s.44-45. 
"Hazırlanan bir manevra filmini görmeye gelmiştim, toplantıda olduğunuzu öğrenince sizlerle görüşmek, hepinizi tanımak istedim "dediler. Bu söz bizleri mesut etti, bir anda bütün endişelerimizi unuttuk. $O$, birimizin değil, hepimizin sevgilisi oldu. Derinliklerinde şimşeklerin ışıkları kaynaşan mavi gözlerini hepimizin üstünde gezdirdi, çalışmamı hakkında sorular sordu. Karşısında kendisine cevap verebilen genç kızları görmek onu memnun etmişti. Aza kayıt defterini istediler, adlar üzerinde duruyordu... Birden başını kaldırıp: "buradaki kayıtlara göre mevcudunuz az" dedi. Cevap bekler gibi yüzümüze baktı. Kendisine kolejlilerin leyli olduklarlnı gönüllü hemşirelerin de vazifede bulundukları için gelemediklerini söyledik. Aldığımız kararlarl yakınları vasıtasıyla kendilerine bildireceğimizi söyledik. Memnun oldular, faaliyetlerimize hız vermememizi çalışmamızı arttırmamızı tavsiye ettiler."

Mustafa Kemal Paşa uzun bir masa etrafinda toplanan cemiyet üyelerine; kadınların millete analık edeceği için kendini yetiştirmesini, Türk ocaklarındaki konferanslara, toplantılara gidip cemiyetin davalarını yakından takip etmesi tavsiyelerinde bulunmuştur. Bütün milletin felaketlere karşı dayanışmada birleşmesini, yardıma ihtiyaçları olursa kendisine gelebileceklerini söylemiştir. Aslında bu ziyaret, Asri Kadın Cemiyeti'nin şeref üyeliği ricasının kabulü anlamına da gelmiştir. Mustafa Kemal Paşa zaten Naciye Faham, Sabahat ve Melahat Hüsamettin Hanımların subay olan babalarını yakından tanımaktaydı ve bu kadınlarla yolları sürekli kesişecekti. Dr. Rasim Ferit Bey de kültürlü, iyi eğitimli vatansever olarak bu kadınların Mustafa Kemal Paşa ile tanışıklığını artırması için çaba göstermiştir. Hatta Mustafa Kemal Paşa şerefine evinde verdiği bir davete cemiyet üyelerinden Selma Köprülü, Melahat ve Sabahat Hanımları da davet ederek Asri Kadın Cemiyeti'ni daha yakından tanımasını sağlamıştır. Sabahat Filmer o geceye dair anılarında Mustafa Kemal Paşa'nın bir ara kalabalığa dönerek "Bu genç kızlar çok iyi çalışlyor, büyük işler yaplyorlar...” dediğini aktarmaktadır. Mustafa Kemal Paşa'nın yakın ilgisi cemiyet üyelerini memnun ederken onunla daha çok görüşme istekleri de artmıştır. Melahat Hanım'ın doğum günü bunun için bir firsat olarak görülerek Asri Kadın Cemiyetinin faal üyelerinin katılacağı kutlamaya Mustafa Kemal Paşa ve Dr. Rasim Ferit Bey'i de davet etmişlerdir. Mustafa Kemal Paşa, Melahat Hanım'ın 16 Nisan 1919'daki doğum günü kutlaması için aldığı davete ülkesi için çalışan kadınları bir arada görüp konuşmak isteğiyle katılmayı kabul etmiştir. İstanbul'da bulunduğu günlerde Asri Kadın Cemiyeti'nin faaliyetlerini dikkatle izlemiştir. ${ }^{25}$

\section{Asri Kadın Cemiyeti ve İşgaller Karşısında İlk Tepkiler}

Mondros Mütarekesi sonrasında yaşanan işgallere tepkinin gösterildiği, işgal kuvvetlerinin protesto edildiği ilk açık hava toplantısı 19 Mart 1919 tarihinde Asri Kadın

Sabahat Filmer, Atatürk Yolunda..., s.36. 
Cemiyeti ve İnas Darülfünunu tarafından kadınların katılımıyla Fatih Türbesi’nde bir anma töreni yapılmıştır. Asri Kadın Cemiyeti Başkanı Naciye Faham ve genel sekreter Aliye Esad hanımların öncülük ettiği bu toplantıya cemiyet üyeleri, İnas Darülfünunu öğrencileri ve halkın katılımı da yoğun olmuştur. Törene saat üçte başlanmış ve katılımcılardan bir kısmı öncelikle türbe içinde toplanarak Kur'an-1 Kerim tilavet eylemişlerdir. Okunan dualardan sonra Darülfünun Edebiyat Fakültesi'nden bir kız öğrenci tarafindan Abdülhak Hamit Bey'in "Türbe-i Fatihi Ziyaret" manzumesi okunmuştur. ${ }^{26}$ Ardından Darülfünun mezunlarından Mediha Muzaffer Hanım İstanbul'un Türklerde kalacağına dair bir konuşma yapmıştır. Konuşmasıyla toplantıya katılanları coşturmuş ve "Ístanbul'dan gitmeyiz! Gitmeyiz! Gitmeyiz" sözlerini toplantıya katılan bütün hanımlar hep bir ağızdan tekrarlamışlardır. ${ }^{27}$

Daha sonra Asri Kadın Cemiyeti adına Naciye Faham Hanım söz almış; "Ulu hakanın türbesini yabancı nazar altında bırakmayacă̆ını yumruklarını sıkarak" diyerek büyük bir heyecan içinde haykırmıştır. Ülkenin içinde bulunduğu zor koşulları anlatarak konuşmasına şu şekilde son vermiştir:

"Milletin fikrini milletin kuvvetini zerre kadar kale almadan ve ona muhalif olarak hareket eden harp kabinesi bir sebeb-i siyasi ve idari ve belki de bir sebeb-i askeri uğrunda Ermenilerden bazılarını nakil bazılarını da tehcire lüzum görmüşlerse bundan bütün millet niçin mesul olsun?" 28 Savaş yıllarında İttihat ve Terakki Partisi’nin izlediği politikalardan dolayı bir milletin cezalandırılamayacağını ifade ederek haksız işgallere tepki göstermiştir.

Genç Kadın Dergisi'nde Fatih türbesinde kadınların yaptığ etki şöyle aktarılmıştır:

"Türk kadınlığının milli, sarsılmaz bir iman ile tertip ettiği bu samimi ziyaret, Türk erkekleri için ne intibahaver bir vaka idi! Türk kadınlarının bu pek ulvi ve tarihi tezahürleri, Türkiye'nin her yerinde, her aile yurdunda heyecanlı bir hüsn-i kabule mazhar oldu. Yüzlerce münevver, hamiyetli Türk kadının iştirakiyle ve derin bir iman-ı milli ile tertip edilen bu ulvi ziyaret yüce hakanın ruh-ı muazzamını şad ettiğine hiç şüphe yoktur." 29

26 “İstanbul Türk Kalacaktır”, İkdam, 20 Mart 1919, s.2.; Emine Önhan, İkinci Meşrutiyet'ten Cumhuriyet'in İlanına Kadar Kadın Cemiyetleri, Atatürk Üniversitesi Atatürk İlkeleri ve İnkılap Tarihi Enstitüsü Yayımlanmamış Yüksek Lisans Tezi, Erzurum 1990, s.63.

27 "Ulvi Bir Tezahür", Genç Kadın, S.7, 27 Mart 1919, s.108.

28 “İstanbul Türk Kalacaktır”, İkdam, 20 Mart 1919, s.2.; Ulvi Bir Tezahür”, Genç Kadın, S.7, 27 Mart 1919, s.108.

29 “Ulvi Bir Tezahür”, Genç Kadın, S.7, 27 Mart 1919, s.108. 
Asri Kadın Cemiyeti ve İnas Darülfünunu'nun girişimi ve yüzlerce eğitimli kadının katılımıyla işgalci güçleri protesto etmek amacıyla Fatih Türbesi önünde yapılan bu toplantı İzmir'in işgali sonrasında yapılacak mitinglerin de öncüsü olmuştur. ${ }^{30}$

\section{Asri Kadın Cemiyeti’nin Öncülüğünde Kadın Örgütlerinin Ortak Muhtırası}

Asri Kadın Cemiyeti'nin daveti üzerine 28 Mart 1919 günü Milli Terbiye ve Talim Cemiyeti binasında kadın örgütlerinin katılımıyla bir toplantı yapılmıştır. Bu toplantıya İstanbul'da bulunan on iki kadın cemiyeti temsilci göndermek suretiyle katılmışlardır. İnas Darülfünunu adına Fatma, Sabahat Hüsameddin, Sanayi-i Nefise Mektebi'nden Mediha, Bakiye, Şişli Cemiyet-i Hayriyesi’nden Rukiye, İnayet, Esirgeme Derneği'nden Matlube Ömer, Rana Sani, Musiki Muhibbi Hanımlar Cemiyeti'nden Muhlise, Himaye-i Etfal'den Saliha Ruşen Eşref, Asri Kadın Cemiyeti'nden Selma, Naciye, Ticaret Mektebi İnas kısmından Mediha Hakkı, İslam Kadınları Çalıştırma Cemiyeti'nden Azize Sami, Muallimler Cemiyeti'nden Zahide, Emine, Türk Ocağı'ndan Melahat Hüsameddin, Biçki Yurdu'ndan Şadiye ve Samiye Hakkı Hanımlar bu toplantıda hazır bulunmuşlardır. ${ }^{31}$

Cemiyet, Mondros Mütarekesi ertesinde Fransız siyasi temsilcilerine bir muhtıra taktim ederek bununla yaşanan acılar karşısında kadınlığın sakin ve ilgisiz kalmadığını duyurmuştur. Fransız makamları tarafından bu muhtıra kabul edilmiş, Fransa devlet başkanı da bu önemli mesele ile bizzat meşgul olacağını vadetmiştir. Hatta Türk hanımlarına hürmetlerini ve selamlarını göndermiştir. Bu muhtıralardan İngiliz ve Amerika mümessillerine de takdim edilirse onların da aynı nezaketle kabul edeceği düşünülmüştür. Bu nedenle Asri Kadın Cemiyeti, yabancıların dikkatini çekmek üzere bir muhtıra hazırlanması için kadın cemiyetlerine öncülük yapmıştır. Ayrıca bu muhtıranın Beynelmilel Kadınlar Cemiyeti'ne ${ }^{32}$ de gönderilmesi üzerinde durulmuştur. Lady Aberdeen'in başkanlık ettiği Beynelmilel Kadınlar Cemiyeti'nin Türk kadınının yaşadığ1 acıları görmezden gelemeyeceği düşünülmüştür. Türk kadınlarının büyük zorluklar içinde kurup yaşattığı cemiyetlerin ülkesinin kurtuluşu için verdiği mücadelesini dünyaya tanıtmak amaçlanmıştır. Hilal-i Ahmer, Esirgeme Derneği, Himaye-i Etfal Cemiyeti,

30 Afet İnan, Tarih Boyunca Türk Kadının Hak ve Görevleri, İstanbul, Milli Eğitim Basımevi, 1975, s.104; Müjgân Cunbur, "Millı̂ Mücadele Mitinglerinde Türk Kadının Yaptığg Konuşmalar”, Millî Mücadelede Türk Kadını, Haz. İnci Engünün vd., Ankara, Cumhuriyetin 60. Yıldönümü Yayınları, 1983, s.14.

31 "Hanımlarımızın Mühim Bir İçtimaı-Kadın Cemiyetlerinin Teşrik-i Mesaisi”, Yeni Gazete, 29 Mart 1919, s.2.

32 Beynelmilel Kadınlar Cemiyeti, 1888 yılında Washington'da kurulmuş ve 25 ülkeden yirmi milyon civarında üyesi olan dönemin güçlü bir uluslararası kadın örgütüdür. Bkz: "Kadınlar da Karışıyor”, İkdam, 8 Mart 1919, s.1. 
Biçki Yurdu, İstihlak-ı Milli Kadınlar Cemiyeti, Kadınları Çalıştırma Cemiyeti, Muallimler Cemiyeti, Türk Ocağı, Sanayi-i Nefise Mektebi, Darülfünun, Asri Kadın Cemiyeti gibi kadınların aktif olduğu örgütlerin birlikte hareket etmesi üzerinde durulmuştur. Asri Kadın Cemiyeti bu müesseselerin baş başa vererek Türk kadının da Avrupa ve Amerika'nın medeni kadınlarına katılması gerekliliğine dikkat çekmiştir. Onların da bu muhtıra ile Türk kadınının feryadına şahit olacağı düşünülmüştür. Asri Kadın Cemiyeti, toplantıya katılan cemiyetlerin üyelerinin "ilmi fikirlerinden” büyük yardım beklediğini de açıklamıştır. Asri Kadın Cemiyeti’nin bu girişimine detaylı bir şekilde yer veren nadir yayın organlarından biri olan Yeni Gazete kadınların bu girişimini desteklenmekle birlikte eleştiri de getirmiştir. ABD Başkanı Wilson'a her gün pek çok milletten yüzlerce, binlerce muhtıra gönderildiğini, gönderilecek bu muhtıranın belki bin birinci muhtıra olacağını, bu konuda geç kalındığını iddia etmiştir. Kadınların ayrıca bir muhtıra göndermelerine gerek olmadığı, başka derneklerin gönderdikleri muhtıraları imzalamalarının yeterli olduğunu savunmuştur. ${ }^{33}$

Muhtıra hazırlamak üzere yapılan müzakereler 1 Nisan 1919 günü yapılan toplantı da devam etmiştir. Nihayet 21 Nisan 1919'da yapılan son toplantıda muhtıra hazırlığ1nın tamamlandığı Asri Kadın Cemiyeti Katib-i Umumiliği’nin 22 Nisan 1919 tarihinde İkdam, Yeni Gazete, Ati, Hadisat gibi gazetelere verdiği bir ilanla duyurulmuştur. Muhtıranın doğrudan doğruya Uluslararası Kadınlar Cemiyeti başkanı Lady Alberdeen’e gönderileceği ilan edilmiştir. ${ }^{34}$

\section{Milli Kongre ve Asri Kadın Cemiyeti}

Asri Kadınlar Cemiyeti, Mütareke döneminde, İstanbul'da “Milli Müdafaa” hareketinin örgütlenmesine katkıda bulunmak amacıyla kurulan Milli Kongre Cemiyeti içinde yer alan kadın örgütlerinden biri olmuştur. Milli Kongre Cemiyeti, işgaller karşısında millet olarak birlikte hareket etmenin gerekli olduğunu gören Dr. Esat Paşa tarafindan parti ve cemiyetlerin tek çatı altında çalışması için 29 Kasım 1918'de kurulmuştur. Çok sayıda kadın örgütü, kadın delegeleriyle ve tam temsil gücüyle bu cemiyete katılmıştır. Milli Kongre'nin Milli Talim ve Terbiye Cemiyeti salonunda yapılan ilk toplantısına siyasi parti ve cemiyetler ikişer üye göndererek destek vermişlerdir. ${ }^{35}$

33 "Hanımlarımızın Mühim Bir İçtimaı-Kadın Cemiyetlerinin Teşrik-i Mesaisi”, Yeni Gazete, 29 Mart 1919, s.2.

34 “Asri Kadın Cemiyeti Katib-i Umumliğinden”, İkdam, 22 Nisan 1919, s.2; "Hanımlarımızın Faaliyeti”, Hadisat, 22 Nisan 1919, s.1; “Asri Kadın Cemiyeti Katib-i Umumliğinden”, Ati, 22 Nisan 1919, s.2.

35 Tarık Zafer Tunaya, Türkiye'de Siyasal Partiler, C.2, İstanbul, İletişim Yayınları, 2011, s.171; Yaprak Zihnioğlu, Kadınsı Inkllap..., s.93. 
Asri Kadın Cemiyeti, Milli Kongre'den sonra kurulduğundan bu oluşuma geç dâhil olmakla birlikte 1919 yılı toplantılarında Asri Kadın Cemiyeti'nin oldukça etkili olduğu görülmektedir. İzmir'in işgali sonrasında İstanbul'da protesto mitingleri düzenlenmesinde ve halka direniş ruhunun aşılanmasında Milli Kongre liderlik yapmış mitinglerin organizasyonunda Asri Kadın Cemiyeti'nden büyük destek görmüştür. Milli Kongre'nin 19 Mayıs 1919 tarihli toplantısına katılan cemiyet İzmir'in işgalini protesto etmek ve ülkenin içinde bulunduğu feci durumu izah etmek amacıyla ABD Başkanı Wilson'a bir telgraf gönderilmesi kararının alınmasında öncü olmuştur. ${ }^{36}$ Milli Kongre'nin ülkede yaşanan haksız işgaller karşısında telgraf protestosuyla başlattığ mücadele etkili olmuş kısa sürede İstanbul'da medeni dünyada önemli yankılar uyandıracak mitingler düzenlenmeye başlamıştır. ${ }^{37}$

\section{Protesto Mitingleri ve Asri Kadın Cemiyeti}

İstanbul' da ülkenin içinde bulunduğu belirsizlik ve işgal tehlikelerine karşı kıpırdanmaya başlayan tepkileri 15 Mayıs 1919'da Yunanistan'ın İzmir'i işgali iyice tetiklemiştir. İzmir'in işgali, Asri Kadınlar Cemiyeti üyelerini derinden etkilemiş ve hemen bir gün sonra cemiyet merkezinde 16 Mayıs 1919 günü bir toplantı yapılarak ülkenin kurtuluşu yolunda yapılacaklar üzerinde durularak önemli kararlar alınmıştır. Cemiyet, 19 Mayıs 1919 tarihinde İstanbul'da başlayacak seri protesto mitinglerinin hazırlanmasına öncülük yapmıştır. Cemiyet üyesi Sabahat Hanım bu sürece dair şunları anlatmaktadır: ${ }^{38}$

"Başta bütün üniversiteliler olmak üzere, tam teşkilatlı kadın kuruluşlarının hepsi, hakka, hürriyete âşı olan vatandaşlar, mukaddes topraklarını seven herkes birleşip duydukları isyanı memleketimizin sathına yaymaya çalışacak. Bunun için devamlı protesto mitingleri hazırlanacak, bir program dâhilinde yapılacak bu toplantılarda kalbi yanan, sesi duyulan dili söyleyebilen herkes konuşacaktı. Bunu tatbik edebilmek için her tehlikeyi göze almıştık."

İlk olarak Darülfünun öğrencileri 18 Mayıs 1919'da bir toplantı düzenlemişlerdir. Darülfünun'da dersler boykot edilmiş ve öğretmen ve öğrencilerden yoğun katılımının olduğu toplantıda kürsüde konuşma yapmak üzere her fakülteden temsilciler seçilmiştir. Hukuk Fakültesi'nden Muslihiddin Bey ile Tıp Fakültesi'nden Akil Muhtar Bey'in konuşmasından sonra Rıza Tevfik Bey’in kürsüye çıktığı toplantıda, dönemin kaynaklarında ismi belirtilmediği için kim olduğunu tespit edemediğimiz İnas Darülfünunu'ndan bir hanım da söz almıştır. ${ }^{39}$ Konuşma Tasvir-i Efkâr Gazetesi'nde şu şekilde yer almıştır:

36 "Milli Kongre'den", Vakit, 20 Mayıs 1919, s.2.

37 Zekeriya Türkmen, Millî Mücadele Yıllarında İstanbul Mitingleri, Ankara, Berikan Yayınevi, 2016, s.47.

38 Sabahat Filmer, Atatürk Yolunda ..., s.47-48.

39 “İzmir Hadisesinin İstanbul Vilayetindeki Tesiratı", İkdam, 19 Mayıs 1919, s.1. 
"Türk Gençliğinin nısfinı biz teşkil ediyoruz. Biz de aynı fikirdeyiz. Türk gençliği her daim kadınlığı, münevver kadınlığı yanında görecektir. Buna emin olunuz. İcap ederse gençlik yanında ve vatan uğruna biz de öleceğiz." ${ }^{40}$

Konuşmasında kadınların da erkeklerle beraber mücadeleye hazır olduğunu belirterek sözlerini şöyle sonlandırmıştır: "Teşebbüsatınıza en kavi bir imanla iştirak ediyor ve şu hakikati isma etmek (duyurmak) istiyoruz: Kim demiş bir kadın küçük şeydir, Bir kadın belki en büyük şeydir." Toplantı sonunda İstanbul'un muhtelif semtlerindeki meydanlarda protesto mitingleri yapılması kararlaştırılmıştır.

İlk miting 19 Mayıs 1919 tarihinde Fatih meydanında düzenlenmiştir. Bütün okullar, müesseseler tatil edilmiş ve Fatih parkında genç-yaşlı, kadın-erkek İstanbul halkının katılımıyla büyük bir miting düzenlemiştir. ${ }^{41}$ Geniş katılımın olduğu mitingin beş konuşmacısından ikisi kadın olup bunlar, Halide Edip Hanım ve Darülfünun öğrencisi Meliha Hanımdır. Daha önce birçok kapalı salonda konuşma yapan Halide Edip Hanım ilk kez bir açık hava toplantısında konuşma yapmıştır. Bu olay Türk kadının miting kürsüsüne ilk çıkışı olmuştur. Halide Edip Hanım kadınlara seslenerek büyük bir inançla içinde bulunulan tüm olumsuz koşullara karşı mücadele için çağrıda bulunup ellerindeki gücü hatırlatmıştır. $^{42}$

Darülfünun öğrencisi Meliha Hanım da heyecanlı bir konuşma yaparak ülkeyi içine düştüğü durumdan kurtarmak için mücadele etme gereği üzerinde durarak halkı mücadeleye çağırmıştır. Konuşmasını hak ve adalete vurgu yapan şu sözlerle sonlandırmıştır:

«Vatanımızı kurtarmak için yaşayacă̆ız kuvvetle iman ediyoruz ki büyük Allah'ımıza sı̆̆ınarak, cebir ile alınan bir hak elbette iade edilecektir. ",43

İstanbul' da yapılan ikinci miting Fatih mitinginin ertesi günü 20 Mayıs 1919 tarihinde Üsküdar Doğancılar'da yapılmıştır. Kadın-erkek 30 bin kişinin katıldığg toplantının sekiz konuşmacısından üçü kadın olmuştur. Bunlar, Asri Kadın Cemiyeti adına Sabahat ve Naciye Hanımlar ile Üsküdar Sanayi Mektebi Fransızca Öğretmeni Zeliha Hanımdır. ${ }^{44}$ Miting gününe dair Sabahat Filmer anılarında şunları anlatmaktadır: ${ }^{45}$

40 “Darülfünun'da İçtima ve Tezahüratın Devamı”, Tasvir-i Efkâr, 19 Mayıs 1919, s.1.

41 "Fatih'te İstanbul Ahalisinin Muazzam Mitingi”, Memleket, 20 May1s 1919, s.1.; "Sevgili İzmir İçin İstanbul Müslümanlarının Dünkü Tezahüratı”, İkdam, 20 Mayıs 1919, s.1.

42 Zeki Saruhan, Kurtuluş Savaşı Kadınları, Ankara, Cem Web Ofset, 2006, s.89.

43 Kemal Arıburnu, Millî Mücadelede İstanbul Mitingleri, Ankara, Yeni Desen Matbaası, 1975, s.18.

44 Sarıhan, Kurtuluş Savaşı ..., s.92.; "Dün de Üsküdar'da Büyük Bir İçtima Akd Edildi”, Hadisat, 21 Mayıs 1919, s.1.

45 Sabahat Filmer, Atatürk Yolunda ..., s.49. 
"Doğancılardaki bir mezarlı̆̆ın demir parmaklıkları önünde toplandık. Gözlerimizin önünde renkli bir halı gibi uzanan büyük bir kalabalık vardı. Coşan halk, güneşe, rüzgâra bakmıyor, durmadan dalgalanıyor, her an biraz daha büyüyordu. Bugünkü konuşmacılar Asri Kadın Cemiyeti'nden iki üniversiteli idi. Naciye Faham ve ben Sabahat Hüsameddin. İkimiz de halkın heyecanı karşısında büyülenmiş gibi idik. Ben sesimde hıçkırıklar, gözümde yaşlar dolu olarak konuştum."

Sabahat Hanım, İzmir'in işgali karşısında duyduğu üzüntü ile konuşmasına şöyle başlamıştır: ${ }^{46}$

"Ey Muhterem talihsiz ahalimiz!

Dün muazzez Fatihimizin yüksek ve muhteşem minareleri altında ecdadımızın ruhlarından yükselen tekbirleri duyarak bir vaz'ı huşu ve hürmetle toplanan, ağlayan 50.000 feryada bugün de yeni sesler, yeni avazeler karışıyor. Biz temsil ettiğimiz asri Asri Kadın Cemiyeti şahsiyeti maneviyesinden de bu seslerin derinliklerinde gür ve kudretli bir hak olduğunu söylemek istiyoruz. Çünkü hepimiz ayn kederle malulüz. Hepimiz gasp olunan bir hak karşısında yaşıyoruz. Fakat bugün en çok biz kadınlar, o anneler, kardeşler bedbaht memleketimizde sükûn ve istirahatle yaşamak hakkını kazanmak için ailelerimizin kıymettar vücutlarını birer birer kaybederken bile bu kadar keder duymuyorduk."

İzmir'den sonra sıranın Konya'ya, Bursa'ya hatta İstanbul'a geleceğini üzüntüyle haykırarak "bizi biraz daha ölüme yaklaştıran bu kahir kuvvetler karşısında yine böyle sükûn ve tevekkül ile mi yaşayacă̆ız? Ben buna hayır diyorum. Biz kadınlar bu cihadında en önde olacă̆ız ve medeniyete riyalar, yalan söyleyen varlıklara her zaman lanetler, lanetler edeceğiz. Artık bu son zulmün önünde biz kadın erkek, genç ihtiyar hepimiz birleşelim..." sözleriyle kadınları mücadeleye çağırmıştır. İşgalleri sakin bir şekilde karşılamayacağız diyerek kadınların hak mücadelesinde en önde olacağını söylemiştir. Konuşmasına işgaller karşısında kadınlara düşen görevi hatırlatarak şöyle son vermiştir:

"Mazisinde şanlar şerefler parlayan bir milletin bugünkü evlatlarına kadınlarına düşen vazife sesleri kısılıncaya kadar bağırmak ve haklarının karşısında susmamaktır. Evet, muhterem gençler sevgili islamlar (yaklaşık iki satır sansüre uğradiğından çıkartılmış) yürümekten hareketten kaçmayalım. Çok eminim ki arkamızda peygamberimizin ruhaniyeti. Allahımızın koruculuğu vardır. Çünkü şimdi biz çok hem pek çok mazlumuz."

Sabahat Hanım’ın dini motiflere yer verdiği son cümleleri halkı daha da coşturmuş ve meydanı dolduran kalabalığın duygularına tercüman olmuştur.

Üsküdar mitinginin Asri Kadın Cemiyeti üyesi bir diğer hatibi Naciye Faham Hanım'ın konuşması ise şu şekildedir:

46 “İzmir Hadisesi Milletin Kalbine Kök Saldı”, İkdam, 21 Mayıs 1919, s.1. 
"Necip Türk ve Müslüman kardeşler:

Biz tarihin belki arzın şahit olmadığı ihtilalli bir inkılabın kara bahtl yavruları, biz bedbaht evlatlarl, bize dört kanlı senenin matemli mersiyesini bile bize çok gören medeni insanlar son darbeleriyle can evimizi yaraladılar. Fakat büyük bir ekseriyet-i hayata sahip olan İslamlar bu kadar haksız bu kadar şeni tagallübün intikamını beşiklerden mezarlara kadar taşıyacaklardır. İzmir mülkümüzün tarih hayatından coğrafyasından silinemez. Çünkü onda asılarca yaşayan ferdin hatıralarl, Türk abideleri tamamıyla Türk zeybekleri, efeleri var. Ona sahip olmak isteyenler bu canlı abide-i hamaseti hâkimiyetleri altında yaşamazlar. Muhterem kardaşlar! Biz eğer vatanımızın kanll yaralarına bir insicam ve tesanütle sarılır, onun tedavisine kırılmaz bir azim dönmez bir sebatla koşarsak elinde bütün bu yüksekliklerin maverasında titreyen hak, adalet ve müzahirimiz olacaktır. Düşününüz efendiler siz bu cidalde yalnı değilsiniz. Arkanızda yanık bağırlarıyla yaşlı kederleriyle koşan yetişen kadınlar analarınız kardaşlarınız evlatlarınız var. Yaşasın bütün millet ve âlem-i İslam."

Naciye Hanım da miting meydanını dolduran kalabalıktan İzmir'in işgaline karşı direniş için çağrıda bulunmuştur. Bu mücadelede erkeklerin yalnız olmadığı, arkalarında kadınların olduğunu belirtmiştir. ${ }^{47}$ Döneme hâkim olan milliyetçilik fikrinin ektisiyle konuşmasında Türklük vurgusu öne çıkmıştır. Konuşmaların ortak noktası vatanseverlik olup miting sonunda Fatih mitinginde alınan kararlar aynen benimsenmiştir. ${ }^{48}$

Asri Kadın Cemiyeti'nin destek verdiği bir diğer miting ise 22 Mayıs 1919 tarihinde yağmura rağmen yaklaşık 20 bin kişinin katıldığı Kadıköy mitingi olmuştur. Bu mitingin kadın hatipleri, İnas Darülfünunu öğrencisi Münevver Saime Hanım, yazar Hayriye Melek ve Halide Edip Hanımlar olmuştur. Asri Kadın Cemiyeti 23 Mayıs 1919'da düzenlenen Sultan Ahmet mitingine de destek vermiş cemiyet üyeleri geniş katılım göstermişlerdir. Halide Edip Hanım'ın yaptığı konuşma ile ünlenen miting, İstanbul'da yapılan mitingler arasında en çok katılımın yaşandığı miting olmuştur. ${ }^{49}$

İstanbul Polis Müdürlüğü çok geçmeden bu mitinglerin düzenlenmesini yasaklamıştır. Ancak 30 Mayıs 1919 tarihinde Sultanahmet'te bir dua yapmak amacıyla toplanılacağı ilan edilmiş ve oldukça geniş katılımlı bir miting yapılmıştır. Burada ise Darülfünun öğrencisi ve Asri Kadın Cemiyeti üyesi olan Şukufe Nihal Hanım vatan sevgisi temalı bir konuşma yapmışırı. ${ }^{50}$ Şukufe Nihal Hanım; "Mezarımın önüne gelen yabancılar, senin kabrinden cebren ayırmak istedikleri vefakâr çocuklarından birinin sana ebediyen

47 Kemal Arıburnu, Millî Mücadelede..., s.26.

48 “Üsküdar'da İkinci Büyük Miting”, Vakit, 21 Mayıs 1919, s.1-2.

49 Kemal Arıburnu, Milli Mücadelede...,s.39.; Afet İnan, Tarih Boyunca..., s.106.; "Yüz Bin Müslüman Sultan Ahmet Meydanında Muazzam Bir Miting Akd Eyledi”, İkdam, 24 Mayıs 1919, s.1.

50 Hülya Argunşah, Bir Cumhuriyet Kadını Şukufe Nihal, İstanbul, Timaş Yayınları, 2011, s.73. 
ağlayan mezarı karşısında her zaman bu memleketin garibi olduklarını anlayarak titremeyeceklerdir" sözleri ile halkı coşturmuştur. ${ }^{51}$ Sultanahmet mitingi ile ilgili haberler dönemin basınında büyük ölçüde sansüre uğramış gazetelerde mitinge dair sütunlar boş çıkmıştır.

Mitingler halk arasında millî birlik ve beraberlik ruhunu güçlendirirken millî mücadele fikrinin geniş kitlelerce benimsenmesinde önemli rol oynamıştır. Asri Kadın Cemiyeti üyelerinin İstanbul mitinglerinde; Türklük, vatan sevgisi, kadınlık, Müslümanlık, analık, şehitlik özgürlük gibi motiflere yer verdikleri konuşmaları Anadolu'da yapılan kadın mitinglerinde de örnek alınıp benzer konuşmalar yapılmıştır. Yurt genelinde yapılan mitingler ulusal direniş yönünde kamuoyunun oluşmasında, ulusal bağımsızlık doğrultusunda kitlelerin mobilize oluşunda, Kuva-yı Milliye ruhunun kadın-erkek geniş kitlelere yayılmasında etkili olmuştur.

\section{Asri Kadın Cemiyeti’nin Kadınların Siyasal Hakları Meselesine Bakışı}

I. Dünya Savaşı ile tüm dünyada kadının statüsünde büyük bir değişim yaşanıp kadınlar sosyal ve iktisadi alanlarda kendini göstermeye başlarken kadınların siyasal hakları konusu da tartışılmaya başlanmıştır. Savaş ertesinde özellikle Avrupa kamuoyunu meşgul eden bu konu Osmanlı kadınlarınca da yakından takip edilmiştir. Osmanlı Devleti'nde 1919 Aralık ayında Osmanlı Mebusan Meclisi için yapılacak seçimler Türk ve Müslüman kadınların da siyasal hakları meselesini gündeme getirmiştir. Vakit Gazetesi kadınlar arasında bir anket yaparak kadınların seçme ve seçilme hakkı konusundaki görüşlerini sütunlarına taşımak istemiştir. Amerikan Koleji Müdiresi, muallimleri, öğrencileri, Bezm-i Alem Sultanisi Müdiresi Hatice Hanım, Darülmuallimat Müdiresi Samiye Hanım, Nakiye Hanım, Halide Edip Hanım gibi eğitimci ve aydınlarla birlikte kadın örgütlerinin bu konudaki görüşlerine başvurulmuştur. Ankete katılan iki cemiyet Müslüman Kadınlar Birliği ve Asri Kadın Cemiyeti olmuştur. Türk kadınına seçme hakkının verilmesine olumlu yaklaşıp mebus seçilebilmek için gerekli şartlar ve seçilecek kadın mebuslar bağlamında görüş bildirmişlerdir. ${ }^{52}$

Vakit Gazetesi muhabiri, Asri Kadın Cemiyeti merkezine giderek cemiyet adına Başkan Naciye Hanım'ın kadınlara seçme ve seçilme hakkı verilip verilmemesi hakkındaki fikirlerini almıştır. İlk soru "Kadınlara hakk-ı intihabı veriyor musunuz, efendim?"

51 Afet İnan, Tarih Boyunca..., s.106.; Leyla Kaplan, Cemiyetlerde ve..., s.77.

52 Serkan Tuna, "Son Osmanlı Mebusan Meclisi Seçimleri Sürecinde Siyasi Bir Anket: Türk Kadınına Seçim Hakkı Verilmeli mi?”, Cumhuriyet Tarihi Araştırmaları Dergisi, Yı1:12, S.23, Bahar 2016, s.30. 
olmuştur. Kadınların seçim hakkına sahip olmasına olumlu bakan Naciye Hanım, kadının da erkeğin de bu toprakların saadet ve felaketiyle alakadar bulunduğunu kadınların ihmal edilmemesi gerektiğini belirtmiş̧ir. Asri Kadın Cemiyeti'nin kadınların sosyal konumlarını yükseltmek ve yirminci asrın istediği dereceye çıkarmak için çalıştığını ifade etmiştir. Zaten kadınlara seçme hakkı verilmesi ihtiyacıyla da bir araya geldiklerini de eklemiştir. Anketin ikinci sorusu "Bizim kadınlarımızı bu hakkı laylkıyla istimal etmeye hazır buluyor musunuz?" olup Naciye Hanım eğitim eksenli bir yanıt vermiştir. Türk kadınını seçme ve seçilme hakkı konusunda tamamıyla "liyakatlı" görmediğini belirterek "insan olmadığından bile haberi olmayan kadınlarımız var" demiştir. Bu koşullarda seçme ve seçilme hakkı istemek ortaya çok zayıf kuvvetlerle çıkmak anlamına gelecektir. Fakat Avrupa'daki kadın ve erkeğin durumu daha yüksek olmakla birlikte, Osmanlı toplumu içinde de son altı sene zarfinda dikkate değer inkılaplar gerçekleşmiştir. Bu dönemde erkekler arasından birçok eğitimli gençler şehit düşmüş, birçoğu da eğitimini tamamlayamamıştır. Hâlbuki bu altı sene zarfında kadınlar için birçok okul açıldığı gibi kadınlar hayatın içinde daha fazla yer almaya başlamışlardır. Kadının seviyesi pek farklı bir tarzda geliştiği halde erkeklerinki duraklama içerisine girmiştir. Gelinen noktada artık birçok eğitim görmüş kadın olduğunu belirterek bu kişilerin seçim hakkını elde etmeleri durumunda ülkenin menfaatini düşünerek hareket edeceklerine emin olduğunu söylemiştir. Dolayısıyla cemiyetin, kısa bir zaman için yalnız eğitim görmüş kadınların seçime katılmalarını arzu ettiğini de eklemiştir. Naciye Hanım erkekler açısından da sadece eğitim görmüş olanların seçime katılmaları gerektiğini ifade etmiş ve o zamana kadar böyle olmadığ için ülkenin menfaatine uygun bir şekilde hareket edilmediğini de söylemiştir. ${ }^{53}$

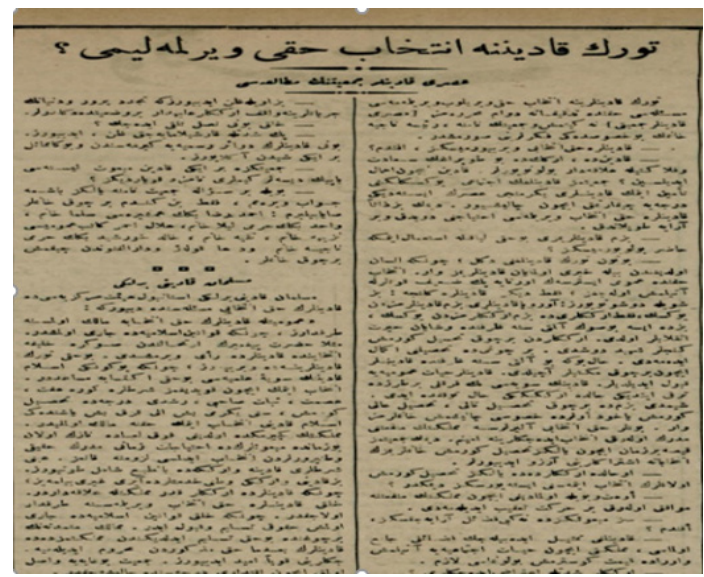

(Türk Kadınına İntihap Hakkı Verilmeli mi?”, Vakit, 1 Kasım 1919, s.2.) 
"Siz mebusunuzda ne gibi fezail (faziletler) arayacaksını, efendim?" sorusuna ise Naciye Hanım'ın cevabı şöyle olmuştur: “Kadınlığı temsil edebilecek fezaili cami olmasl, memleketi için hayat-ı içtimaiyeye atılmış ve orada kıymet göstermiş bulunması lazım." "Erkekler şiddetle itiraz edecekler mi?" sorusuna ise ilerlemeden yana olan ve dünyadaki gelişmelere vakıf erkeklerin, kadınların seçim hakkına itiraz etmeyeceklerini zannettiğini ifade etmiştir. "Halk bunu nasıl telakki edecek?" sorusuna yanıtı ise halkın içinden de pek şiddetli bir tepki gelmeyeceği yönünde olmuştur. Bunun kadınların resmi dairelere girmesi gibi örneklerden de anlaşılacağını belirtmiştir. Naciye Hanım, Vakit Gazetesi muhabirinin "Cemiyetinize bir iki kadın mebus listesi yapın deseler kimleri namzet koyardınız?" şeklindeki son sorusuna ise "böyle bir suale cemiyet namına yalnız başıma cevap veremem, fakat ben birçok hanımlar sayabilirim" demiştir. Ayrıca; Ahmet Rıza Bey’in kız kardeşi Selma Hanım, Vahit Bey’in eşi Leyla Hanım, Hilal-i Ahmer Cemiyeti Genel Sekreteri Nezihe Hanım, Feyziye Mektebi Müdiresi Nakiye Hanım, Halit Hurşit Bey'in eşi Naciye Hanım ile kolej ve Darülfünun' dan mezun birçok kadının mebus seçilebileceğini söylemiştir. ${ }^{54}$

Kadınların eğitimi ve kültürel açıdan bilgilendirilmesini amaçlayan Asri Kadın Cemiyeti, kadınların siyasal haklarına sahip olması gerektiğini savunmuştur. Ancak kadınların siyasal haklarına kavuşması Cumhuriyet döneminde gerçekleşebilmiştir. Cemiyet üyelerinden Naciye Faham, Aliye Esad, Şukufe Nihal Hanımlar kadın haklarının savunuculuğunu yapmışlar, Türk Kadınlar Birliği içerisinde etkin görevlerde bulunmuşlardır. ${ }^{55}$ Cemiyet üyelerinden Melahat Ziya Hanım, 1930 yılında Türk kadına belediye seçimlerinde seçme seçilme hakkının tanınmasıyla Ankara Belediye Meclisine seçilen ilk kadın üyelerden biri olmuştur. ${ }^{56}$

\section{Asri Kadın Cemiyeti’nin Diğer Faaliyetleri}

Asri Kadın Cemiyeti kadınları bedenen ve fikren eğitmek, toplumsal konumlarını yükseltmek ve bu hedefe ulaşabilmek için kütüphane, müze, laboratuvar ve atölyeler amaçlamıştır. Ancak cemiyet, Mondros Mütarekesi sonrasında ülkede işgallerin yaşanmaya başladığı bir dönemde kurulduğundan, öncelikli olarak ülkenin kurtuluşu için çalışmalara yönelmiştir. Cemiyetin kurucu üyelerinden biri olan Sabahat Filmer anılarında cemiyetin faaliyetleriyle ilgili şunları anlatmaktadır: "Cemiyetimizde kadınları

54 “Türk Kadınına İntihap Hakkı Verilmeli mi?”, Vakit, 1 Kasım 1919, s.2; Serkan Tuna, "Son Osmanlı Mebusan Seçimleri Sürecinde Siyasi Bir Anket: Türk Kadınına Seçim Hakkı Verilmeli mi”, s.41

55 Yaprak Zihnioğlu, Kadınsız Inkılap..., s.157-158.

56 Murat Karataş, “Erken Cumhuriyet Dönemi’nde Siyasal Bir Portre: Ziya Gevher Etili”, Selçuk Üniversitesi Türkiyat Araştırmaları Dergisi, S.35, 2016, s.342-343. 
aydınlatmak, cehaletten kurtarmak, medeni haklarını temin savaşına yardımcı olmak, kimsesiz çocukları korumak gibi manevi desteklemelerden başka, hastalara bakmak, cephedeki askerlere gömlek, çamaşır, sargı hazırlamak, yaralılarla meşgul olmak da vazifemizdi." İtilaf Devletleri'nin denetimi altında olan başkent İstanbul'da çok yoğun bir çalışma faaliyeti yürüten cemiyet, kısa sürede işgal güçlerinin dikkatini çekmiş ve istihbarat ajanları tarafından takip edilmiştir. Cemiyet üyeleri bu nedenle daha dikkatli hareket etmek zorunda kalmıştır. ${ }^{57}$

Cemiyet, kuruluş amacına uygun kültürel faaliyetlerde de bulunmuş kadınların eğitimi için kurslar düzenlemiştir. Okuma-yazma ve Kuran yanında Fransızca, Almanca ve İngilizce dersleri verilmiştir. Kadınların bu kurslara ilgisini arttırmak için Asri Kadın Cemiyeti Kâtip-i Umumiliği'nin gazetelere verdiği ilanı şu şekildedir: “Cemiyetimiz merkezinde yevmi dersler verileceğinden arzu eden her Türk ve İslam kadını istifade edebilir. Kayıt zamanları: Cumartesi, Çarşamba saat ikiden sonra. Dersler: Türkçe, Kuran, Kıraat, Imla, Fransizca, Almanca, Ingilizce." ${ }^{58}$ Dersler, cemiyet merkezi olarak kullanılan Bilgi Yurdu Müessesesinin dershanelerinde verilmiştir. ${ }^{59}$

Mütareke döneminde Asri Kadın Cemiyeti’nin öncülük ettiği önemli kültürel faaliyetlerden biri şair Tevfik Fikret'in ölümünün dördüncü yıl dönümü vesilesiyle Darülfünun Edebiyat Fakültesi Öğrenci Derneği ile 19 Ağustos 1919'da düzenlediği anma töreni olmuştur. Asri Kadın Cemiyeti Katib-i Umumiliği törenden bir gün önce verdiği bir gazete ilanı ile Tevfik Fikret' in mezarında yapılacak anma törenine kadınları şöyle davet etmiştir: "Fikret merhumun sene-i devriye-i vefatı münasebetiyle salı günü sabahleyin ziyarete gidileceğinden cemiyetimiz azalarıla Darülfünun, Darülmulallimat, sultani müntesipleri, hariçten arzu eden, Fikret'i seven her Türk kadını iştirak ermek üzere Eyüp Sultan'daki makber-i mahsusasına ziyarete gelebilir. Vapur köprüden Eyüp'e saat 9'da hareket edecektir." 60

Dönemin basınında da geniş yer verilen bu anma törenine kız-erkek bütün Darülfünunlar, şairin dostları, meslektaşları ve öğrencileri katılmıştır. Tevfik Fikret'in Eyüp’teki mezarına gitmişler, ayrıca Aşiyan'da da bir anma toplantısı düzenlemişlerdir. Mezarı başında Cemiyet üyesi Saime Hanım şairin bir mersiyesini okumuştur. ${ }^{61}$

57 Sabahat Filmer, Atatürk Yolunda ..., s.35.

58 “Asri Kadın Cemiyeti”, Vakit, 8 Ağustos 1929, s.2.

59 BOA, DH.EUM.5.Şb, 79-30, 12, H-30-12-1337.

60 "Fikret'in Kabrini Ziyaret", Vakit, 18 Ağustos 1919, s.2.

61 Zeki Saruhan, Kurtuluş Savaşı..., s.117.; Tevfik Fikret'in Günü, İkdam, 20 Ağustos 1919, s.1. 
Asri Kadın Cemiyeti, gelir sağlamak amacıyla 1920 yılı başında bir de cep takvimi hazırlanmış ve cemiyet tarafından satışa sunulmuştur. "Asri Kadın Cemiyeti Cep Takvimleri” başlığıyla dönemin gazetelerinde reklamları yapılarak geniş kitlelere ulaştırmak hedeflenmiştir. Cemiyetin gazetelere verdiği ilan şu şekildedir:

"Medeni ihtiyaçlarınızı tatmin etmek, telefon, adres, küçük hatıralarınızı temiz yapraklar arasında saklamak, mevsim tahvilatın, tarihi ananeleri, büyük, mukaddes günlerinizi bilmek isterseniz elinizde bu bedii küçük takvim bulunmalıdır. Mahall-i tevzi Halk Kütüphanesidir. Taşradan da sipariş kabul olunur." 62

İstanbul'da 12 Ocak 1920'de açılan son Osmanlı Mebusan Meclisi'nin açılışı münasebetiyle Asri Kadın Cemiyeti, bir kutlama telgrafı göndermiştir. Meclisin 22 Ocak 1920 tarihli oturumunda çok sayıda tebrik telgrafı gönderildiğinden müzakereleri uzatmamak adına bunların okunmaması ve Meclis başkanlığınca bir teşekkürle karşılık verilmesi kararlaştırılmıştır. ${ }^{63}$

Asri Kadın Cemiyeti, 16 Mart 1920'de İstanbul'un işgaline kadar olan süreçte İstanbul'da önemli faaliyetlerde bulunmuştur. Cemiyet, Mustafa Kemal Paşa liderliğinde Anadolu'da başlayan Millî Mücadele'ye inanmış ve destek vermiştir. Naciye Faham, Şukufe Nihal gibi cemiyet üyeleri Anadolu'daki harekete yardımcı olan Karakol gibi gizli örgütlenmelerde de görev almışlardır. ${ }^{64}$ Asri Kadın Cemiyeti Mustafa Kemal Paşa’yı ve Millî Mücadele’yi büyük bir dikkatle takip etmiştir. Örneğin TBMM ordusunun kazandığ 1 Sakarya zaferi münasebetiyle Mustafa Kemal Paşa'ya bir tebrik mektubu göndermiştir. Mustafa Kemal Paşa da 14 Ekim 1921 tarihli bir cevabi mektupla Asri Kadın Cemiyeti'ne teşekkürlerini şöyle ifade etmiştir: “Ordumuzun kazandığı Sakarya zaferi münasebetiyle hakkımda ibraz buyurulan tebrikat ve hissiyat-l kalbiyeleri beni pek tahassüse etti. Teşekkürler ederim."65 Mustafa Kemal Paşa'nın annesi Zübeyde Hanım'ın 14 Ocak 1923 'te vefatı üzerine duyulan üzüntüyü bildirmek üzere de cemiyet adına başkan Naciye Faham imzalı bir taziye telgrafı göndermiştir.66

\footnotetext{
62 “Asri Kadın Cemiyeti Cep Takvimi”, Vakit, 21 Ocak 1920, s.4; “Asri Kadın Cemiyeti Cep Takvimi”, Illeri, 21 Ocak 1920, s.6.

63 Türkiye Büyük Millet Meclisi Zabıt Ceridesi (TBMMZC), Devre:4, Cilt:1, İçtima Senesi:1, 22 Ocak 1920, s.18.

64 Hülya Argunşah, Bir Cemiyet..., s.56.

$65 C A, 010106678-5$.

66 CA, 01014886-355.
} 


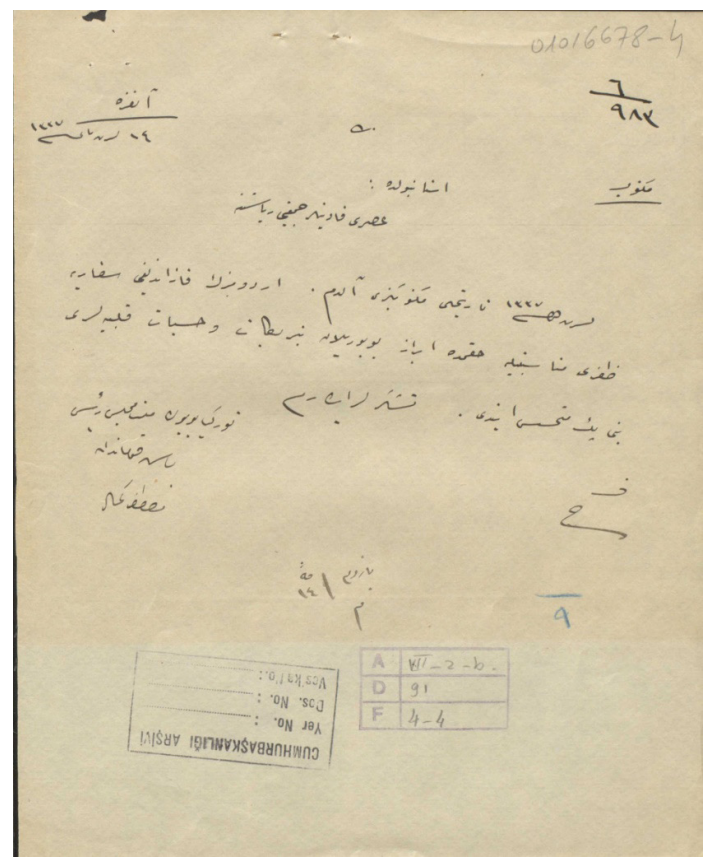

(Mustafa Kemal Paşa'nın Asri Kadın Cemiyeti'nin Sakarya zaferi münasebetiyle gönderdiği tebrik mektubuna cevabi. CA, 010106678-5.)

Cumhuriyet dönemiyle birlikte Asri Kadın Cemiyeti'nin faaliyetleri son bulmuştur. Türkiye'nin az sayıdaki üniversite mezunu kadınları olan cemiyet üyelerinden Sabahat Filmer gibi isimler öğretmenlik yaparken Naciye Faham, Aliye Esad (Pirigil), Şukufe Nihal (Başer) hanımlar da kadınların eğitimi ve hakları mücadeleyi sürdürmüşlerdir. Örneğin, Aliye Esad ve Şukufe Nihal Hanımlar 1923 yılında Nezihe Muhiddin Hanım'ın öncülüğünde kurulan ancak faaliyete geçemeyen Kadınlar Halk Fırkasının kurucu üyeleri arasında yer almışlardır. Hatta Şukufe Nihal Hanım Fırka'nın genel sekreterliğine seçilmiştir. ${ }^{67}$ Naciye Faham Hanım ise Medeni Kanunu'nun hazırlanması sürecinde Türk Ocağı'nın girişimi ile kadınlardan oluşan bir komisyonda görev almıştır. ${ }^{68}$ Aliye Esad ve Şukufe Nihal hanımlar kadınların haklarını savunmak üzere Şubat 1924'te kurulan Türk Kadınlar Birliği içerisinde de etkin görevler almışlardır. Asri Kadın Cemiyeti’nin genel sekreterliğini yapan ve cemiyetçilikte büyük deneyim kazanmış Aliye Esad Hanım 1927-1935 yılları arasında Türk Kadınlar Birliği’nin de genel sekreterliğini yapmıştır. ${ }^{69}$

67 Yaprak Zihnioğlu, Kadınsız Inkılap ..., s.130-131.

68 Bernard Caporal, Kemalizmde ve..., s.361.

69 Yaprak Zihnioğlu, Kadınsız Inkılap..., s.157-158. 


\section{Sonuç}

I.Dünya Savaşı yıllarında tüm dünyada olduğu gibi Osmanlı Devleti'nde kadının statüsünde büyük bir değişim yaşanmış ve kadınlar sosyal ve iktisadi alanlarda kendini göstermeye başlamışlardır. Savaş yıllarında kadın örgütlerinin sayısında büyük bir artış yaşanmıştır. Mondros Mütarekesi sonrasında yaşanan işgaller karşısında İstanbul kadınları sessiz kalmamış cemiyetler aracılı̆̆ıyla tepki göstermişlerdir. İstanbul'da İnas Darülfünunu mezunları ve öğrencileri tarafından 1918 yılı sonlarında kurulan Asri Kadın Cemiyeti Mütareke Dönemi’nin en etkin kadın örgütlerinden biri olmuştur.

Asri Kadın Cemiyeti, özellikle 15 Mayıs 1919'da İzmir'in işgali sonrasında İstanbul'da yapılan protesto mitinglerinin düzenlenmesine de öncülük yapmıştır. İlk defa açık hava toplantılarında meydanlara toplanan kadın erkek karışık topluluklar önünde kadınlar kürsüye çıkıp konuşmuşlardır. Asri Kadın Cemiyeti'nden Naciye Faham Hanım, Sabahat Hanım, Şukufe Nihal Hanımlar mitinglerde Türklük vurgusunun öne çıktığı heyecanlı konuşmalar yapmışlardır. Müslümanlık, vatan sevgisi, kadınlık, özgürlük, analık, şehitlik gibi motiflerin yer aldığı konuşmalarıyla miting kürsülerinden halkı coşturmuşlardır. Vatanın bütünlüğü ve milletin bağımsızlığ için erkeklerle birlikte mücadeleye hazır olduklarını haykırmışlardır. Mitingler halk arasında millî birlik ve beraberlik ruhunu güçlendirirken millî mücadele fikrinin geniş kitlelerce benimsenmesinde önemli rol oynamıştır.

Cemiyet, kadınların eğitimi için de kurslar düzenleyerek çeşitli kültürel faaliyetlerde bulunmuştur. Asri Kadın Cemiyeti modern İstanbul kadınının yüzü olmuş özellikle kadın hakları meselelerinde fikri sorulan bir merci haline de gelmiştir. Türkiye'nin ilk üniversite mezunu kadınları olan cemiyet üyeleri kadınların eğitimi ve hakları için çaba göstermişlerdir. Cemiyet, 16 Mart 1920'de İstanbul'un resmen işgali sonrasında pek etkinlik gösterememiştir. Ancak Anadolu'da Mustafa Kemal Paşa'nın liderliğinde yapılan Millî Mücadeleyi dikkatle takip etmiştir. Cumhuriyet döneminde Asri Kadın Cemiyeti'nin faaliyetleri son bulurken Aliye Esad, Şukufe Nihal gibi cemiyet üyeleri Türk Kadınlar Birliği gibi örgütler içinde faaliyetlerini sürdürmüşlerdir.

Hakem Değerlendirmesi: Dış bağımsız.

Çıkar Çatışması: Yazar çıkar çatışması bildirmemiştir.

Finansal Destek: Yazar bu çalışma için finansal destek almadığını beyan etmiştir.

Peer-review: Externally peer-reviewed.

Conflict of Interest: The author has no conflict of interest to declare.

Grant Support: The author declared that this study has received no financial support. 


\section{KAYNAKÇA}

\section{Arşiv Belgeleri ${ }^{70}$}

Türkiye Cumhuriyeti Cumhurbaşkanlığı Devlet Arşivleri Başkanlığı Osmanlı Arşivi (BOA)

Türkiye Cumhuriyeti Cumhurbaşkanlığı Arşivi (CA)

\section{Süreli Yayınlar}

Ati

Hadisat

Ikdam

Ileri

Inci

Memleket

Müşahede

Tasvir-i Efkâr

Türk Kadını

Vakit

Yeni Gazete

\section{Araştırma Eserler}

Argunşah, Hülya: Bir Cumhuriyet Kadını Şukufe Nihal, İstanbul, Timaş Yayınları, 2011. Arıburnu, Kemal: Millî Mücadelede İstanbul Mitingleri, Ankara, Yeni Desen Matbaası, 1975. Baskın, Bahar: "II.Meşrutiyet’te KadınEğitimine Yönelik Bir Girişim: İnas Darülfünunu”, İ.Ü. Siyasal Bilgiler Fakültesi Dergisi, No:38, Mart 2008, s.89-123.

Caporal, Bernard: Kemalizmde ve Kemalizm Sonrasinda Türk Kadını (1919-1970), Ankara, Türkiye İş Bankası Kültür Yayınları, 1982.

Cunbur, Müjgan: "Millî Mücadele Mitinglerinde Türk Kadının Yaptığı Konuşmalar", Millî Mücadelede Türk Kadını, Haz.İnci Engünün, Müjgan Cunbur- Cahide Özdemir, Ankara, Cumhuriyetin 60. Yıldönümü Yayınları, 1983, s.14-32.

Çakır, Serpil: Osmanlı Kadın Hareketi, İstanbul, Metis Yayınları, 2011.

Filmer, Sabahat: Atatürk Yolunda Büyük Adımlar, İstanbul, Gül Matbaası, 1983.

İnan, Afet: Tarih Boyunca Türk Kadının Hak ve Görevleri, İstanbul, Milli Eğitim Basımevi, 1975. 
Karataş, Murat: “Erken Cumhuriyet Dönemi’nde Siyasal Bir Portre: Ziya Gevher Etili”, Selçuk Üniversitesi Türkiyat Araştırmaları Dergisi, 2016, S.35, s.341-375.

Kaplan, Leyla: Cemiyetlerde ve Siyasi Teşkilatlarda Türk Kadını (1908-1960), Ankara, ATAM Yayınları, 1998.

Türkiye Büyük Millet Meclisi Zabıt Ceridesi, Devre:4, Cilt:1, İçtima Senesi:1, 22 Ocak 1920.

Önhan, Emine: İkinci Meşrutiyet'ten Cumhuriyet'in İlanına Kadar Kadın Cemiyetleri, Atatürk Üniversitesi Atatürk İlkeleri ve İnkılap Tarihi Enstitüsü Yayımlanmamış Yüksek Lisans Tezi, Erzurum 1990.

Paşalığlu, Hacer Banu: Inas Sanayi-i Nefise Mektebi ve Mezunları, Marmara Üniversitesi Türkiyat Araştırmaları Enstitüsü Yayımlanmamış Yüksek Lisans Tezi, İstanbul 1996. Saruhan, Zeki: Kurtuluş Savaşı Kadınları, Ankara, Cem Web Ofset, 2006.

Tevetoğlu, Fethi: “Atatürk’ün Güvendiği Bir Kişi: Dr.Rasim Ferit Talay”, Atatürk Araştırma Merkezi Dergisi, C.VII, S.21, Temmuz 1991, s.624-638.

Toprak, Zafer: Türkiye'de Kadın Özgürlüğü ve Feminizm (1908-1935), İstanbul, Tarih Vakfi Yurt Yayınları, 2014.

Toprak, Zafer: Türkiye'de Yeni Hayat Inkılap ve Travma (1908-1928), İstanbul, Doğan Kitap, 2017.

Tuna, Serkan: "Son Osmanlı Mebusan Seçimleri Sürecinde Siyasi Bir Anket: Türk Kadınına Seçim Hakkı Verilmeli mi?,” CTAD, Y1l:12, S.23, Bahar 2016, s.25-52.

Tunaya, Tarık Zafer: Türkiye 'de Siyasal Partiler, C.2, İstanbul, İletişim Yayınları, 2011. Türkmen, Zekeriya: Millî Mücadele Yıllarında İstanbul Mitingleri, Ankara, Berikan Yayınevi, 2016.

Zihnioğlu, Yaprak: Kadınsız Inkılap, İstanbul, Metis Yayınları, 2013. 
